\title{
Transformational Learning In Business Education: The Pivotal Role Of Experiential Learning Projects
}

Rita D. Kosnik, Trinity University, USA

Jacob K. Tingle, Trinity University, USA

Edwin L. Blanton, III, Trinity University, USA

\begin{abstract}
In this paper, we posit experiential learning projects in business as a valuable alternative to internships to meet the new AACSB standards for accreditation. While internships have traditionally been used as the main method to provide hands-on learning experiences for students in business schools, their effective implementation imposes stringent demands on faculty, curriculum, and program resources. The pedagogical and administrative benefits of experiential learning projects (ELP) are analyzed using the Kolb model and the literature on learning. We illustrate the versatility of the ELP learning tool by describing two very different applications currently in use at a small private university and advance guidelines for the effective implementation and assessment of experiential learning projects in business curricula.
\end{abstract}

Keywords: Experiential Learning; Business Education; Accreditation

\section{INTRODUCTION}

$\mathrm{n}$ the spring of 2013, the Association to Advance Collegiate Schools of Business (AACSB) launched new standards for accreditation of its member business schools. The revision of the AACSB accreditation standards was a response to the new challenges of creating value in an increasingly global, interactive and fast-changing business world and society. Economic pressures on business schools have forced a paradigm shift in the teaching and learning models required to prepare business school graduates for successful careers and meaningful social and personal lives. Under the newly revised standards, (re)accreditation by AACSB will require that schools provide evidence of ongoing improvement in three areas: 1) innovation, 2) impact, and 3) engagement (AACSB, 2013). AACSB describes the three themes for improvement as follows:

1. Innovation: A successful business education should find creative ways to create value for students, employers, as well as the community in which they function, through an ongoing process of continuous improvement. Rather than relying on traditional, well-established educational methods, the new paradigm emphasizes well-developed and well-planned experimentation with new pedagogical tools and explicitly recognizes that risk of failure should be accepted as an integral component of constructive progress and double-loop learning (Argyris, 2002; Argyris \& Schon, 1996).

2. Impact: A business education should not only be of high quality but should also make a difference through "both scholarly education and impactful intellectual contributions" (AACSB, 2013, p. 2). Besides the traditional focus on providing static business knowledge through theories, modeling and case studies, business programs are now expected to clearly define and demonstrate how their education and their students make a difference in business and society.

3. Engagement: Creating business knowledge that is both scholarly and relevant for practice requires meaningful interactions among faculty, students, and business professionals. The traditional academic model that removed business students from the real world, into the "safe" classroom environment of theory-driven lectures without real world experience, no longer offers adequate preparation for decision- 
making and competitive performance in a global marketplace. Hands-on learning will become a pivotal component of a successful business education.

The core premise that drives these three educational themes is value creation, both from a scholarly and practitioner's point of view. Business schools have been teaching principles of value creation and their value drivers for years in strategy, finance and marketing. The new accreditation standards are demanding that business faculty apply the same value-driven mindset to their own educational strategies.

While the majority of accredited business schools and programs already incorporate components of relevance and hands-on learning in their mission statement and curriculum, what is most striking in the new AACSB teaching paradigm and accreditation standards is the pervasiveness of the educational value concept. Even though business programs are given great freedom to pursue unique, mission-driven objectives and strategies, actively embracing the value-driven principles of innovation, impact, and engagement is pivotal.

\section{VALUE IN BUSINESS EDUCATION}

The new paradigm of value creation in business education extends the range of stakeholders from the traditional student-faculty dyad to include employers and society at large. To accurately assess learning outcomes from each stakeholder's point of view (as required by AACSB), we propose that an effective business curriculum should deliver three distinct sources of educational value: 1) academic value, 2) professional value, and 3) moral value (Figure 1). Students who have effectively developed these three sources of value will be able to make a meaningful contribution to their future employers and to the community.

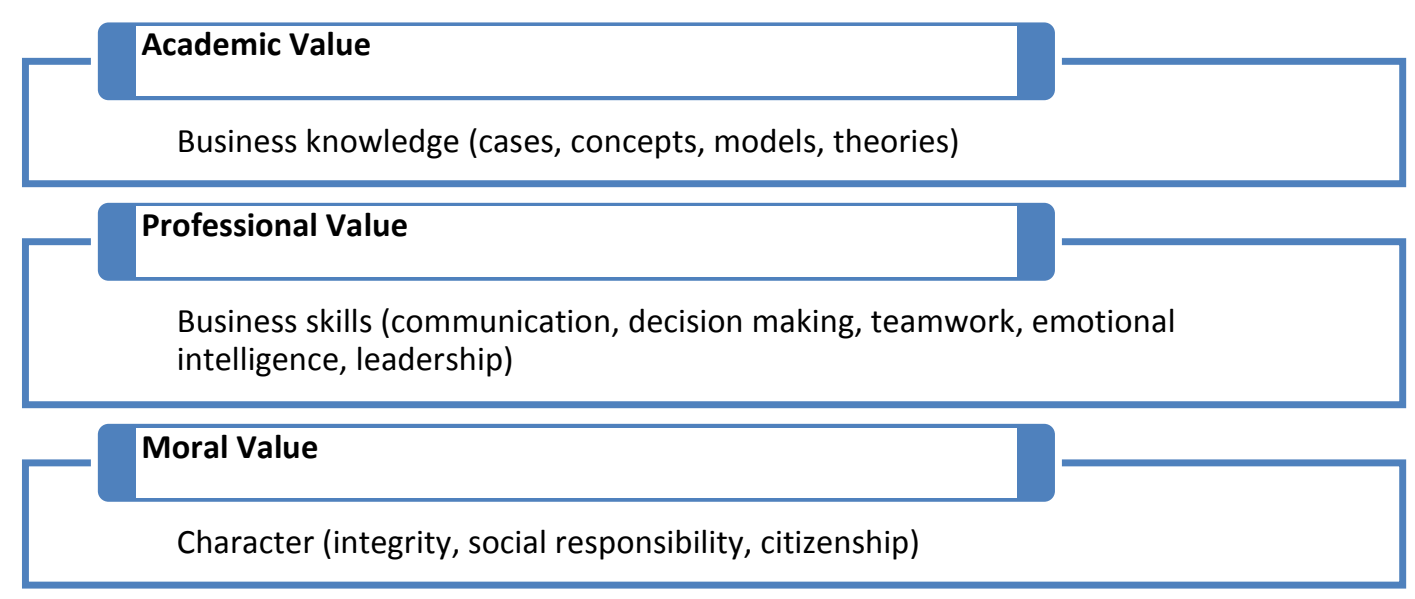

Figure 1: Creating Educational Value through Kolb's Experiential Learning Model

\section{Academic Value}

Academic value represents the business knowledge that is taught in traditional academic settings. Emphasis is on acquiring knowledge of core theories, concepts and models of business and on developing the analytical skills for problem analysis and application. The traditional business curriculum offers students this academic value in a "silo" format of functional areas - accounting, finance, marketing, management, information systems, and operations.

\section{Professional Value}

A business education should provide students with the managerial skills and self-awareness essential to functioning effectively in business and society (Lencioni, 2002; Maxwell, 2007). Current market conditions require very different skills from what was needed to succeed years ago (Aldas, Crispo, Johnson, \& Price, 2010). While test scores and GPAs have been the traditional benchmarks for an effective education, it is now universally recognized 
that equally (if not more) important for a student's long-term post-graduation success are their leadership skills (Lombardo \& Eichinger, 2009) and emotional intelligence ${ }^{1}$ (Goleman, 1995, 2000). These skills constitute the "professional value" that should be delivered by a sound business education - skills in communication, time management, team work, information processing, coping with uncertainty and ambiguity, motivation, and leadership. Our traditional pedagogical methods of lectures, or even case studies, offer students very limited opportunities to fully develop these skills.

\section{Moral Value}

The need for an enhanced sense of social responsibility and ethical conduct among students, employees and managers permeates today's business world. Unethical or socially unacceptable management conduct continues to be among the root causes of corporate failures and highly publicized scandals. AACSB's mission statement and standards highlight the central role of ethics and social responsibility in business education in order to adequately prepare business students for the challenges of today's business environment. Further, AACSB's new themes of impact and engagement require students and business schools to make a contribution to their community. Hence, business programs need to offer their students concrete opportunities to develop their personal moral character and good judgment when faced with social and ethical dilemmas, as well as cultivate their social responsibility. We define this as moral value creation - students assimilate and implement principles of integrity, social responsibility, and citizenship as part of their business education.

In sum, the educational value model that drives the new AACSB standards implies that students should not engage exclusively in purely academic learning but also in personal discovery and the accumulation of tacit knowledge. An experiential, hands-on pedagogy can deliver these requirements.

\section{VALUE CREATION THROUGH EXPERIENTIAL LEARNING PROJECTS}

\section{"Passive Learning is Ineffective and of Short Duration."}

(AACSB, 2012, p. 58)

There is a vast extant literature demonstrating the benefits of active, hands-on learning that gives students the opportunity to directly put their knowledge to use (Armstrong \& Mahmud, 2008; Bonwell \& Eison, 1991; Dees \& Hall, 2012; Devasagayam, Johns-Masten, \& McCollum, 2012; McCarthy \& McCarthy, 2006; Templeton, Updyke, \& Bennett, 2012; Zlotkowski, 1996). The core premise of experiential learning theory is that people (of any age and in various settings) learn best by acquiring new experiences and transforming these experiences into active and tacit knowledge (Kayes, 2002; Nonaka, 1994). The paradigm goes as far back as 1938 when John Dewey (1938) described experiential learning as a philosophy of education based on a "theory of experience." Many scholars, most notably Kurt Lewin, Jean Piaget, William James, Carl Jung, Paulo Freire, and Carl Rogers, embraced the paradigm and highlighted the role of experience in various theories of learning and personal development. Kolb's (1984) experiential learning theory (ELT) is among the best known models. It defines experiential learning as "the process whereby knowledge is created through the transformation of experience" (Kolb, 1984, p. 41). In order to yield effective learning, a new experience needs to be acted upon by analyzing and assessing its meaning and by relating it to past experiences and previously acquired knowledge (Armstrong \& Mahmud, 2008; Wight, 1970). As such, the experience has a "transformational" impact on the learner to the extent that it becomes integrated into the student's "system" of previously acquired constructs and subsequently functions as the lens through which the student observes, interprets, evaluates, and approaches new experiences (Wight, 1970). Because such an educational experience induces a fundamental change in the student's thinking and behavior, we refer to this learning process as 'transformational learning.'

David Kolb's (1984) classic model of experiential learning distinguishes two dimensions in this process. The concrete-abstract dimension represents how an individual interprets the world or perceives new experiences. How one processes incoming information and makes sense of personal experiences is represented by the active-

\footnotetext{
${ }^{1}$ Goleman (1995) defines five dimensions of emotional intelligence: self-awareness, self-regulation of emotions, motivation (taking initiative), empathy and getting along with others.
} 
reflective dimension (Kolb \& Fry, 1975). By integrating the two learning dimensions, Kolb developed a four-stage normative model of effective learning: A concrete experience (Stage 1) should derive meaning through reflective observation (Stage 2) as the learner retracts and attempts to describe the experience (Eyler \& Giles, 1999). The conclusions from this observation should then be conceptualized into a model or theory (Stage 3), which subsequently is tested. This test, known as active experimentation (Stage 4), yields a new experience and induces a new cycle of learning (Sugarman, 1985). As students gain more experience, their performance on tasks that have become routine improves and they evolve to take on more difficult tasks (Alic, 2008). The simplicity and coherence of Kolb's classic learning model makes it an invaluable framework for business schools as they update their teaching methods to meet the new AACSB criteria of innovation, impact, and engagement (Figure 2).

Despite the well-established advantages of active learning methods, business schools are still frequently criticized for having "few active, practical learning experiences" (Templeton et al., 2012, p. 27). Four in five employers participating in a recent survey by the Association of American Colleges and Universities (AAC\&U) would like colleges and universities to place more emphasis on students' ability to apply their knowledge to realworld settings by providing experiential learning experiences (Hart, 2008). The demand for job applicants with practical experience keeps growing as employers scale back their training programs (Green \& Farazmand, 2012). Devasagayam et al. (2012) highlight, "Experiential exercises that demand rigorous engagement and involvement on the part of students are found to be an invaluable pedagogical tool in underscoring and achieving learning objectives related to decision making in a dynamic 'real-life' environment" (p. 1).

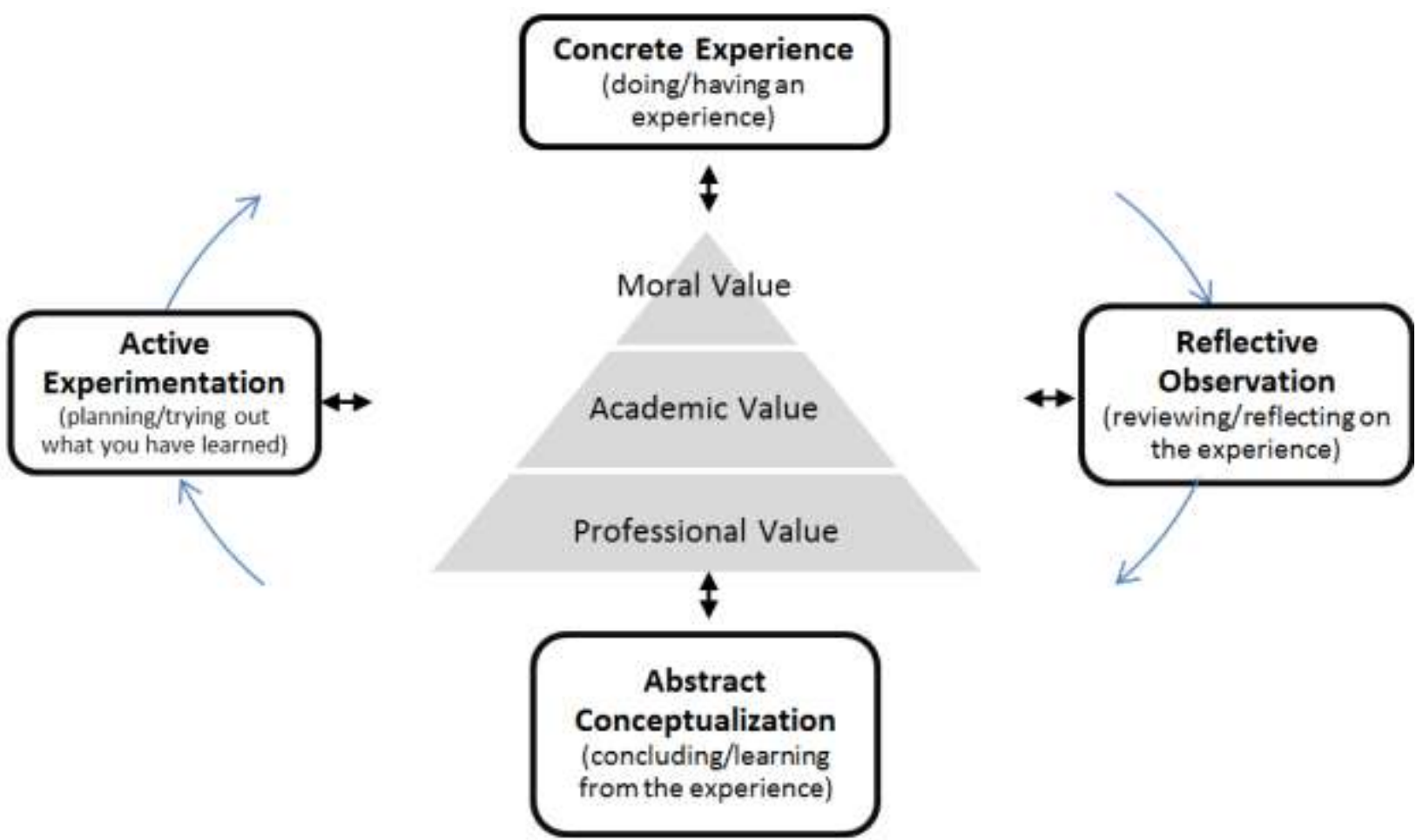

Figure 2: Transformational Learning Using Kolb's Experiential Learning Model

In-class case studies and simulation exercises have been the most traditional methods used by business schools to increase students' active involvement in learning. While widely used to demonstrate the application of business concepts and engage students in critical thinking and discussion, they still retain a certain level of abstraction (McCarthy \& McCarthy, 2006). The safety of the classroom environment and central directive role of the faculty member in the class discussions or exercises can dampen the active engagement of students and the realism of the experience, thereby reducing the impact of Kolb's "concrete experience." These limitations are overcome by internships, now widely embraced by business schools world-wide as the preferred method to give students practical experience and help them transition to the real world. 
Because internships immerse the student into the everyday functioning of organizations, they bring excellent professional value to the student's learning experience. To the extent that the internship requires students to take initiative and make decisions, it also promotes moral value development as the intern learns to practice good judgment, integrity, and foster trust and collaboration with co-workers and supervisors. However, it is more challenging to create consistent academic value through internships. While "...linking of theory and work experience can ... ensure that students see the relevance of their classroom learning" (Templeton et al., 2012, p. 27), many internship experiences are not carried through into the subsequent learning stages of reflective observation and conceptualization as defined by Kolb. Even though many interns keep journals to document the experience and promote reflection, most journals remain merely descriptive and report rather than analyze an intern's activities and experiences. Unless the internship incorporates a significant and well-structured reflective component, such as class discussions, individual faculty coaching, and conceptual paper assignments to "transform" the internship experience, the learning cycle is incomplete and, hence, only moderately effective. Successfully implementing the complete learning cycle for each student's individual internship experience would be highly time-consuming for faculty. Moreover, placing students in individual internships requires an extensive network of host organizations, which needs to be managed by a dedicated staff. Therefore, requiring all students to participate in an internship experience is an expensive curricular strategy that may not be feasible for smaller schools and programs, or for schools located in rural areas.

Experiential learning projects allow business schools to overcome several of the limitations of internships while still offering sound educational value for students (Table 1). An experiential learning project assigns teams of students to a client organization to complete a specific task or consulting project as an integral part of a formal course. As such, it embeds the practical experience directly into the course content and structure. Ross (1990) distinguishes three types of experiential learning opportunities: field work, practicum, and internships.

Table 1: A Comparison of Benefits \& Limitations of Experiential Learning Projects (ELP) and Internships

\begin{tabular}{|c|c|c|}
\hline & Internships & Experiential Learning Projects \\
\hline Benefits & $\begin{array}{ll}\text { - } & \text { Immersion in organization } \\
\text { - } & \text { Realistic job demands } \\
\text { - } & \text { Individualized experience } \\
\text { - } & \text { Helps with career choices } \\
\text { - } & \text { Preparation for employment }\end{array}$ & $\begin{array}{ll}\text { - } & \text { Integration of the learning experience with the } \\
\text { - } & \text { Promotes team work and collaboration } \\
\text { - } & \text { Concentrated and focused learning experience } \\
\text { - } & \text { Faculty guidance and structure } \\
\text { - } & \text { Requires a smaller pool of client organizations } \\
\text { - } & \text { Project driven, not organization driven } \\
\text { - } & \text { Shorter time frame } \\
\text { - } & \text { Explicit assessment of learning outcomes } \\
\end{array}$ \\
\hline Limitations & $\begin{array}{l}\text { - } \text { Time commitment: Requires extensive time } \\
\text { commitment from student } \\
\text { - } \quad \text { Logistics and location: Requires easy access to } \\
\text { local organizations } \\
\text { - } \quad \text { Placement: Individual student assignments require } \\
\text { a large number of hosts } \\
\text { - } \quad \text { Qosts: Requires a dedicated staff and coordination } \\
\text { - } \quad \text { Limity of the experience is variable: Depends on } \\
\text { - } \quad \text { Unstructured learning experience } \\
\text { - Incomplete learning cycle } \\
\text { - Less conducive to team work }\end{array}$ & $\begin{array}{l}\text { - } \quad \text { Limited immersion in client organization } \\
\text { - } \quad \text { Phorter exposure } \\
\text { - } \quad \text { Requires deliberate integration with class } \\
\text { - materials } \\
\text { Faculty member needs consulting and coaching } \\
\text { experience }\end{array}$ \\
\hline
\end{tabular}

Experiential learning projects require more student involvement than field work or a practicum, two alternative learning opportunities that have been well delineated by Ross (1990). In field work, students do volunteer work or shadow managers on an ad hoc basis (Dees \& Hall, 2012). They typically do not work independently and they have limited responsibility. A practicum requires a more extensive commitment from the student to working with an organization, but the student still has limited independence and is typically in a service or assisting role (Ross, 1990). Because experiential learning projects are coordinated and assessed by faculty as a 
component of the course material and class requirements, they can offer more consistent and explicit academic value. Projects can be carefully selected to match the course objectives. In-class activities, lectures, and reading assignments can provide students with the theories, tools, and frameworks to apply in the project. During and after completion of the projects, the reflection and conceptualization stages can be incorporated in class meetings and written assignments. Because of the explicit assessment of students' project performance as part of the course grade, involvement and quality of the work will be higher than for a practicum or internship with a pass/fail or no grade. Another distinctive trait of experiential learning projects is that because they are team projects, students can hone their leadership, social, and team skills.

As such, experiential learning projects combine the benefits of cooperative learning with the advantages of internships: a connection of theory to praxis (Templeton et al., 2012), an improvement in subsequent classroom performance (Green \& Farazmand, 2012), and an inside track to post-graduate employment (Knouse \& Fontenot, 2008). The freedom to engage in real world activities under the guidance of a faculty member further promotes the development of students' creative problem-solving skills (Devasagayam et al., 2012).

\section{EXPERIENTIAL LEARNING IN ACTION: SAMPLE PROJECTS}

The versatility and effectiveness of experiential learning projects can be demonstrated by two pilot projects that were introduced in the management curriculum at Trinity University, a small liberal arts college with select professional programs in business, health care administration, education, and engineering. Business is the largest department and most popular major among its 2,300 undergraduate students. One of the university's key success factors is the close and personalized interaction between students and faculty ${ }^{2}$. Both the University and the Business Administration program highlight hands-on learning as pivotal to their distinct learning environment. While business internships are strongly recommended for business majors, past staffing and faculty constraints have prevented the implementation of an internship requirement for all students. Therefore, in 2010, the business program embraced the gradual implementation of experiential learning projects (ELP) as part of a comprehensive curriculum review.

Two management faculty volunteered to introduce pilot ELPs in their respective upper-division courses, Sport Management and Strategic Management. After two years of running the pilots, the projects have been finetuned using the continuous improvement (Kaizen) premise. The experience gained through the pilot projects is now being used to introduce additional experiential learning projects in the core business curriculum as well as in the various functional areas besides management. The objective is that by 2015 , all business graduates will have completed at least three experiential learning projects by graduation.

While the two pilot projects were distinct and embedded in different courses, their overarching objectives were identical: to build academic, professional, and moral value by reinforcing conceptual learning and creating tangible experiences which will benefit the students post-graduation. Even though the pilot projects preceded the announcement of the 2013 AACSB accreditation standards, they clearly exemplify the new AASCB themes of innovation, impact, and engagement.

\section{Experiential Learning Project (ELP) 1: Sport Management Ticket Sales}

Teams of students enrolled in a Sport Management course were assigned the task of selling game tickets for a local franchise of the American Hockey League (AHL). The course is a three-credit upper division course that meets three times a week and focuses on the foundations of sport management (organizational theory, leadership, budgeting, ethics, and marketing) as they apply to athletics, business, and physical education. Learning objectives for the course include being able to describe personality style/strengths and how those impact team dynamics, exhibiting critical professional skills and attitudes, explaining the relevance of ethical decision making, and displaying an ability to work on a team.

\footnotetext{
${ }^{2}$ The university-wide student-faculty ratio is 11:1. Because of the disproportionate number of business majors, class sizes are higher in business, but still significantly lower than the average business school.
} 


\section{The Project}

The objective of the Ticket Sales ELP was to allow students to create sales strategies, identify target markets, and promote an event through use of student-created marketing pieces. Specifically, students were provided the following learning outcomes which also directed the grade scale for the project:

1. Identify target markets for group sales and possible season ticket sales.

2. Devise strategies, including development of sales timeline and inner-team goals.

3. Recognize trends and patterns to effectively sell your product.

The Ticket Sales project was incorporated into the course by a combination of lectures, presentation, readings and assignments. Over the course of the semester, two class lectures focused on the sales process, three additional class sections were facilitated by the sales manager and one sales staff member from the local AHL franchise, students were required to attend a two-hour phone bank exercise, and the first ten minutes of Friday classes were saved for the sales teams and individuals to discuss past performance and future strategies for goal completion. Additionally, six class days focused on marketing strategy and consumer behavior. Furthermore, the majority of students in the class had completed at least one lower division marketing course. As such, the students had some grounding in marketing and sales strategies but were required to put forth significant out-of-class effort to successfully complete the project.

A total of 60 students participated in the project during two semesters. Students were divided into four teams of seven to eight members based on multiple data points that were collected the first day of class. That information, coupled with the instructor's knowledge of several of the students, was used to create teams that were balanced in terms of the completion of previous business courses, prior sales experience, and extracurricular involvement. The instructor also appointed a team leader for each team. The leader was responsible for communicating with the instructor, the teaching assistant, and the hockey franchise's group sales liaison. The teams' assignment was to sell group tickets for an actual AHL game and function as competing sales teams. Each sales team was required to submit a marketing plan, develop marketing materials, and set specific individual and team ticket sales goals. Because the goal of the project was to give the students real-world experience, the sales process was set-up to mirror that of the AHL team's sales staff. To that end, students were not given tickets on consignment. They were required to develop leads, contact group leaders of those target organizations, set up sales meetings, and close sales by providing an invoice to the purchasing group.

Recognizing that more than half of the students had no previous sales experience, Vroom's (1964) Expectancy Theory was used as a motivational framework. To help students develop the expectation that they could succeed, the following steps were taken. Two class sessions were spent focusing on team formation and development, which allowed the students to get comfortable with their teammates and to form the important bonds of trust upon which they would rely later in the semester. Additionally, early in the semester, veteran ticket sales staff members from the local AHL team spent two class sessions teaching the sales process (using the NBA Model), sales scripting, development of marketing materials, how to prospect group leads, identifying group leaders (5Friends and Family Model), and development of a sales schedule. The two class days after the sales staffs' visit, the professor delivered lectures on sports ticket sales techniques and engaged the students in role play. Lastly, a month into the project, the sales staff members returned and led the class in a two-hour class session to help them refine the art of the cold call.

The Ticket Sales ELP accounted for $25 \%$ of the students' course grade. Armed with a base-line level of expectancy, the professor (with assistance from the AHL franchise) developed a variety of rewards for successfully completing the sales task. In keeping with Vroom's theory, the valence of the reward suggests it should be of significant value to the student. Recognizing that grades are a large driver for students, a grade scale was developed that rewarded students for meeting and exceeding goals. Specifically, goal completion would earn a grade of "B-" and the student would be rewarded (or punished) by exceeding sales goals in various increments (Table 2). Additionally, to replicate the real world aspect of the project, students were rewarded both for individual goal completion and also for team goal completion. The local AHL franchise, owned by a National Basketball Association (NBA) franchise, also offered inducements for the top sales person (interview for internship), the top 
five ticket sellers (lunch with Vice President of Marketing and Sales), and the top team (luxury suite night at a future game).

Table 2: Grade Scale for Ticket Sales Project

\begin{tabular}{|c|c|c|}
\hline & Actual Sales In Relation To Goal & Point Value \\
\hline \multirow{8}{*}{ Team Sales Achievement } & Exceed goal by $50 \%$ or more & 95 \\
\hline & Exceed goal by $25-49 \%$ & 92.5 \\
\hline & Exceed goal by $1-24 \%$ & 87.5 \\
\hline & Meet goal & $81 *$ \\
\hline & Fall short of goal by $1-25 \%$ & 75 \\
\hline & Fall short of goal by $26-50 \%$ & 70 \\
\hline & Fall short of goal by more than $51 \%$ & 45 \\
\hline & Sell zero tickets & 0 \\
\hline \multirow{7}{*}{ Individual Sales Achievement } & Exceed goal by $100 \%$ or more & 47.5 \\
\hline & Exceed goal by $50-99 \%$ & 45 \\
\hline & Exceed goal by $1-49 \%$ & 42.5 \\
\hline & Meet goal & $40.5 * *$ \\
\hline & Fall short of goal by $1-25 \%$ & 32.5 \\
\hline & Fall short of goal by more than $26 \%$ & 22.5 \\
\hline & Sell zero tickets & 0 \\
\hline
\end{tabular}

Notes: * 5 pt. bonus if group goal reached 10 days before game. ** 2.5 pt. bonus if personal goal reached 10 days before game.

\section{Learning Outcome}

In addition to the standardized course evaluation questions administered by the department, participants in the ELP were given a project-specific nine-item survey which consisted of six forced response items and three openended questions (Tables $3 \& 4$ in Appendix). The end-of-course evaluation surveys asked students to assess their own learning experience and gave the instructor insights into their perceptions, challenges, and effectiveness of the process.

\section{Experiential Learning Project (ELP) 2: The Business Solutions Consulting Project}

The Business Solutions Project was a ten-week consulting assignment that was part of a Strategic Management course. Strategic Management is a senior seminar that is required for business students specializing in management but is also available as an advanced elective course for other business students. The course studies strategy implementation and complements a Business Policy course that emphasizes strategy formulation. The main learning objectives of the course are defined as follows:

1. To reinforce the multi-disciplinary nature of a sound business education by integrating and applying the knowledge offered throughout the business curriculum.

2. To prepare students for the transition to the business world and/or graduate school.

The course traditionally relied on the case study method and executive speakers to accomplish these goals. Under the new format, the course was divided into two segments. Segment one consisted of five weeks of "traditional" class meetings aimed at establishing a conceptual and analytical foundation for strategy implementation. Students read books, articles and discussed cases that focused on strategic leadership, organizational life cycles, restructuring, and strategic planning. The second segment of the course (ten weeks) was dedicated to the Business Solutions Project in which students were assigned a consulting project for a local organization. Except for one client in the medical field, all clients were local not-for-profit organizations and included local divisions of Goodwill, the ARC (an organization serving individuals with disabilities), and Each One Teach One (an adult literacy program). The focus on the non-profit sector was a deliberate effort to expose business students to the needs of social groups who face economic, social and/ or physical challenges. 


\section{The Project}

The consulting assignments and deliverables were formulated in a series of meetings between the instructor and each of the clients. Often, the project definition required a few iterations as well as internal negotiations within the client organization in order to secure the necessary organizational support and to align the students' project with the organization's strategic goals and priorities. The client also identified an internal project supervisor who would act as the client's liaison.

Teams of three to five students were assigned one of the following six projects:

1. Develop a business plan for a start-up adult literacy program.

2. Assess the feasibility of and requirements for a professional volunteer program for a large service organization.

3. Assess the efficiency and effectiveness of front office operating procedures at a local medical group practice.

4. Develop a strategic audit and situation analysis for a post-secondary education and enrichment program for young adults with disabilities.

5. Conduct a market analysis and feasibility study for a not-for-profit retirement community initiative.

6. Assess the feasibility and critical success factors for an expansion of work programs into the private sector.

The instructor assigned students to specific teams and projects based on academic performance, their business concentrations (management, marketing, finance, accounting), and their record of leadership and communication skills. As in the Sport Management ELP, the objective was to form well-balanced teams in terms of functional knowledge, analytical and social skills. The latter personality traits were assessed subjectively on the basis of the students' conduct and performance in the first section of the course as well as their performance and conduct in previous courses and school events. During the first year of the project, the instructor selected specific students to function as team leaders and as liaisons with the client and the instructor. During the second year of the project, the instructor did not assign team leaders but only liaisons who would be responsible for external and internal communications and for scheduling meetings. Each team was given the freedom to develop its own structure, roles and leadership. Although this autonomy initially added to the ambiguity and uncertainty experienced by the team members, it did yield well-functioning groups.

Teams were asked to keep a meeting log and minutes to demonstrate their progress; they were expected to dedicate six to ten hours per week to the project. Weekly class meetings were devoted to reviewing the teams' progress and assisting students with research, problem formulation and analysis. The instructor regularly attended out-of-class team meetings and received regular updates from the client.

The consulting process was organized into the following steps:

1. Discovery: Teams were provided with a written outline of the consulting project and a short description of the client. In an initial meeting with the client, the teams learned about the client's organization, its niche and strategic objectives, and the specific expectations for the project.

2. Problem Definition: Most clients provided the students with very broad requests or research questions. The number one challenge for the students at this stage was to define the clients' needs in a concrete problem diagnosis and to analyze the problem's dimensions. For several of the teams, this step took many weeks and several meetings with the client in addition to extensive background research. As will be reflected in the learning outcomes and student feedback, this stage constituted the most challenging part of the project for students because of the uncertainty and ambiguity it encompassed. The instructor's role was to assist the students with formulating the right questions, help them narrow the scope of the project and define the goals and outcomes. Since the projects were to be completed in a ten-week time span, it was essential that the project scope and deliverables were feasible and realistic.

3. Problem Analysis and Research: The students developed a situation analysis of the client, researched the issues to be dealt with in the academic and trade literature, and collected benchmarking data. At this stage, the teams had developed enough momentum to make significant progress in a short amount of time. The 
students also regained a sense of control of the project because all of them had been exposed to academic and business research in previous courses and they were now dealing with concrete facts. The research phase also provided the teams with ideas for solutions and design options for the deliverables. The critical role of the instructor at this phase was to act as the gatekeeper and ensure that the teams had a thorough understanding of the problem and its dimensions before jumping prematurely to the solution phase without sufficiently exploring alternatives and implementation issues.

4. Crafting the Product: The final weeks of the project were dedicated to putting together the deliverables and preparing the report and presentation. This implementation stage was fast-paced and intense; students typically encountered a few unexpected pitfalls and hurdles as they integrated the information they had collected in previous stages and applied models and tools to the problem at hand. As the final product materialized, teams often became overly eager to finish the project. The instructor's role here was to urge students to go back to the initial project assignment and problem definition and verify that their product met the initial expectations and objectives.

5. Reporting: Each team presented their research findings and recommendations to the client in a written report and a formal presentation. In preparation for the client presentation, each team made a practice presentation to the rest of the class and students critiqued the presentation and asked questions. This practice session constituted one of the highlights of the ELP as students engaged in very professional but highly critical discussions of each team's presentation content and style. In order to accomplish this step effectively, the instructor had to create a safe and comfortable environment for open exchange. This was realized during the first part of the semester as the instructor engaged the students in spirited case discussions and as she modeled the role of devils' advocate to stimulate creative and critical thinking. After the practice presentation, teams incorporated the critiques into a final revision of the presentation and report. This last step of preparation proved to be essential for the quality of the final client presentation and report.

The Business Solutions Project was implemented during two semesters with 27 students. The project constituted $40 \%$ of the course grade. Students were graded on their project performance as follows: written report $(50 \%)$, presentation $(30 \%)$, practice presentation $(10 \%)$, and peer evaluation $(10 \%)$. Except for the peer evaluation, all grades were team-based. The instructor assigned the grade in consultation with the client. The individual peer evaluation was included to provide a disincentive for loafing. Students submitted a confidential evaluation of the contribution and active participation of each team member using a five-point scale. Students who were identified by their team members as exceptional contributors received the maximum score for participation. Students who were identified by the majority of their team members as not having participated as much as the rest of the team or who failed to attend the majority of the team meetings received a $25 \%$ reduction in the project grade.

\section{Learning Outcome}

Similar to the Ticket Sales ELP, standard course evaluations were complemented with feedback from participants to document the effectiveness of the learning experience. Participants provided feedback and reflected on their learning experience in three ways. First, the instructor met with each team at the end of the project and facilitated a group discussion concerning the benefits and challenges of the project. Second, students were invited to write an individual evaluation of their learning experience, guided by the following three questions: 1) What did the consulting project teach you about your strengths and weaknesses? 2) What did the consulting project teach you about team work, dealing with other people, leadership? 3) What would you do differently next time? Third, the first cohort of students who had participated in the Business Solutions EPL was surveyed one year after its completion and post-graduation with a response rate of fifty percent.

\section{Assessing the Educational Value of Experiential Learning Projects}

Both projects yielded very positive student evaluations. In the Sport Management project, 26 out of 48 students who responded listed the Ticket Sales ELP as the single most beneficial aspect of the entire course. Students in the Business Solutions project consistently highlighted the practical experience as the main benefit of the project. In open-ended questions, many students made specific comments regarding the tangible post-graduate benefits of the project and its unique challenges. For example: 
I would definitely suggest this class to other students regardless of their major simply because it forces you to use skills that everyone as an employee of any company will need to be able to make a sale.

I feel like this project was an effective way to make us realize how the real world operates in terms of consulting. I think it's just fabulous to engage in something you have no idea about, then learn so many new things and finally be able to help out other people/clients.

Despite their diverse context and activities, the two pilot projects were highly consistent in their delivery of academic, professional, and moral value for students.

Academic Value

Both ELPs emphasized the integration and hands-on application of business knowledge that students had acquired previously in various functional business courses. The traditional silo model of function-specific business education often leads to a fragmentation of the business curriculum and inhibits a system-based view and understanding of organizations. As a result, we often witness senior-level business students struggling with capstone business courses such as Business Policy and Strategic Management. Both pilot projects required the students to revisit previously learned business concepts and models and research other relevant models that fit the problem at hand. For the Sport Management Ticket ELP, the emphasis was on marketing and sales; the Business Solutions consulting project required students to accurately diagnose the client's problems and identify relevant tools and models of management, strategy and marketing to apply toward the problem solution. Without a thorough understanding of the business fundamentals and concepts, students would be unable to accurately implement them in the projects. The need to select relevant business principles and tools also encouraged students to practice their analytical skills and enhanced their cognitive development (Sternberger, Ford, \& Hale, 2005).

Several students acknowledged the academic value development offered by the projects:

It's great to have a course that challenges you academically, but also prepares you for real life problems that exist outside of the classroom.

While studying in class and learning concepts/terms is important, I believe applying those skills is much more beneficial.

For many other students, this component proved to be quite challenging:

[The project] definitely took me out of my comfort zone and I struggled a bit... I think the ticket sales project was extremely beneficial. This allowed us to gain sales experience that not many other college students can say they have.

While some students truly excelled in the projects, others struggled with the analytical elements and their applications despite very good grade point averages in previous business courses. Hence, the projects yielded a revealing and highly differential assessment of students' capabilities. Traditional testing methods of exams and quizzes do not always adequately assess students' ability to identify relevant concepts and tools for problem-solving and to correctly apply the chosen models. Involving students in EPLs significantly increased their understanding of the business concepts and models, which should help them retain the information. Because the level of competence and analytical skills varied among team members, we witnessed how students tutored each other and, together, developed a truly cooperative learning experience (Brown \& Ciuffetelli, 2009; Siltala, 2010; Siltala, Suomala, Taatila, \& Keskinen, 2007).

Professional Value

Interestingly, the biggest learning opportunities and challenges of the two pilot ELPs were in the area of professional skills. 
The ticket-sales project was a huge benefit and opportunity for a college student to get real world experience as a part of class. Really awesome and probably favorite part of the class.

Students in the consulting projects were especially challenged in three areas: coping with ambiguity, managing information overload, and critical thinking. First, they had difficulty coping with the initial uncertainty and ambiguity that is inherent in developing a consulting relationship with clients and defining the parameters of the consulting project. They were initially overwhelmed and all of them experienced a lot of anxiety due to the absence of step-by-step guidelines or ready-to-apply models.

[I] also learned about the process of consulting...it's vague and requires lots of decision-making on the part of the consultant, especially if you're working with a start-up.

I enjoyed the process of the project, although it was difficult at times. I enjoyed and disliked how unstructured the project was. Each project was different so it had to be unstructured, but that proved to be frustrating at times. On the other side, I enjoyed it because we could take our project in a lot of different directions.

Second, once the project was delineated and deliverables were more clearly defined, students entered a phase of information overload as they started researching the client's databases, market conditions, and benchmarks. Absorbing, synthesizing and structuring this information was highly challenging for them. The instructor played a pivotal role in guiding them through these challenges without solving the problem for them. Often what students needed most was reassurance or help with structuring the information and highlighting the patterns or key components in their information. Third, the project offered students the opportunity to practice their critical thinking skills, as they had to accurately identify the client's concerns, priorities and constraints in a process of dialogue and questioning. Describing the decision-making involved in the projects, students reflected:

The project ...also exposed me to the difficulty to make decisions in organizations and get actual innovative ideas implemented: definitely not lessons that can be learned from a textbook.

I became overwhelmed because everything was not planned out in my head. It definitely taught me how to be more adaptable.

Successfully completing either project required effective time management and planning skills, teamwork, social skills, and communication and presentation skills. Students were very aware of the personal development that the projects had encouraged as well as the challenges of working in a team:

I learned a lot about what it takes to accomplish something in a group and how the things that motivate people change when their participation is compulsory versus voluntary. Different personality types also respond differently to various motivators. That was something that I really struggled with.

Students' feedback in both projects highlighted the transformational impact of the learning experience: Completing a real task in a concrete business and management setting gave them a realistic preview of career options and work experiences. It encouraged them to actively pursue or eliminate certain career paths.

I talk about it [the project] in interviews all the time. It's wonderful to say I've been a student consultant. . . The company was so impressed with my work, they offered me a job.

Yet others expressed different learning outcomes:

I learned that I am not of the entrepreneurial blood. I had to learn how to be flexible, not just with our organization, but also with my team. Through the project, I learned that I love business writing and marketing.

Although I understand the reasoning behind the ticket sales project, I did not particularly enjoy it. I now know that I do not want to be in ticket sales or even marketing. 
Moral Value

Both pilot projects challenged students in the areas of trust-building and making judgment calls regarding their level of participation and integrity:

I feel the biggest trait I learned in regards to teamwork is trust and having faith that your other group members will be there should a scheduling conflict occur.

Looking back, I took on a lot just because I thought no one else on my team could 'do it.' I wish I would have trusted my team members more by delegating more evenly.

By assigning business students consulting projects that serve not-for-profit organizations, the students became exposed to and sensitized to sub-populations that are economically and socially disadvantaged. This experience was a real eye opener for many. Following are three responses which reveal the deeper-level moral value learning:

More importantly, though, I learned about a huge part of [the] population that explains a lot of the brain drain and human capital problems...

I loved that we had experience with non-profit [clients]. I've referred to that so many times in my graduate experience.

It was cool to be able to help out with a project that was going to be helping others.

This feedback confirms the well-established benefits of service-learning. "By combining theoretical learning and research with real life experimentation and community service, service-learning enhances students' learning and personal growth" (Farazmand, Green, \& Miller, 2010).

The ELPs that were implemented cohered with Kolb's experiential learning model (1984) and the different demands that each polarized position places on a learner. In both ELPs, students had a concrete experience of either selling AHL tickets or consulting for a local organization. Throughout the semester, students in both courses had several opportunities to engage in reflective observation, both guided by their instructor, with their team, as well as independently. The experience, either through the sale (or attempted sale) of tickets or consulting an organization, was translated into an abstract concept and then tested in the active experimentation stage. This testing gave rise to a new experience as students began the cycle again realizing what they learned through their first active experimentation and building on what may have become routine (Alic, 2008). Throughout the semester, the cycle was completed over and over as students had their experience, reflected, conceptualized, and experimented.

In conclusion, we see a special benefit to delivering the three dimensions of educational value through very diverse projects as they reinforce for students the multi-dimensionality of their academic learning, the universal relevance of professional and moral value, and the need for flexibility and adaptability.

I think employers recognize how rare it is to have experience like that so early, where students get to design and manage their own projects. It's such a satisfying feeling to see it through!

Because of my marketing plan consulting that I did through strategic management, I was immediately chosen to work for the firm.

\section{CRITICAL SUCCESS FACTORS FOR EXPERIENTIAL LEARNING PROJECTS}

The pilot projects described here highlight specific conditions that are critical for the effectiveness of experiential learning program: 1) team work, 2) individual and group accountability, and 3) closing the loop. Our critical success factors for ELPs build on the principles of cooperative learning as discussed in Brown and Ciufetelli (2009) and Siltala (2010). 


\section{Teamwork}

A well-balanced and functional team is critical for the success of ELP. In an effort to avoid the major dysfunctions of a team (Lencioni, 2002), faculty members are encouraged to carefully consider the balanced composition of the student teams in terms of functional specialty, communication and leadership skills, and previous work and internship experience. Instructors should allow sufficient time to develop a strong sense of community (Miller, 2011) and trust (Tschannen-Moran, 2004) among the students and team members prior to launching the project. Trust and a sense of community are paramount to the creation of high functioning teams (Dirks \& Skarliki, 2004). Moreover, the development of a trusting team environment improves the students' self-awareness and adaptability. The more self-awareness the students have prior to the project, the more effective the team experience will be. To further facilitate the development of self-awareness, we recommend that students complete either behavioral or personality self-assessment instruments, such as DISC, Kolb Learning Style Inventory, Strengths Finder, prior to engaging in the experiential learning projects. Not only is the feedback provided in these assessment tools useful to create balanced and well-functioning teams, the insights that are gained by the students about their personal behaviors, competencies and personality will enhance their emotional intelligence and help them prepare for the job market or graduate school.

\section{Accountability}

Students should be held accountable to both the team and to the faculty for the scope of their contribution, the quality of their work, and their mastery of the subject (Brown \& Ciufetelli, 2009). It is critical that project expectations and guidelines for performance assessment are clearly articulated, both for teams and for individual team members, in order to minimize social loafing (Siltala, 2010) and to increase the moral value of the experience. Because experiential learning projects offer students a significant degree of initiative and freedom to decide on both the quality and level of their active engagement, being held accountable for the consequences of their decisions and performance is an essential experience that builds professional and moral value. Therefore, the reward structures and grading systems of experiential learning projects need to be designed specifically to fit the project requirements, the clients, as well as the student population that is targeted. So while the experiential learning projects are extremely versatile and offer faculty great flexibility, they do require a more customized approach to teaching and grading.

\section{Closing the Loop}

The educational benefits of experiential learning can only be accomplished through regular and structured reflection and double-loop learning. Instructors should incorporate into the course schedule regular team assessment sessions that focus not just on the progress of the project but also on the team dynamics. Students should be encouraged to apply the new insights and knowledge they have gained from the experiential learning projects in subsequent courses and other hands-on and collaborative learning experiences, such as internships and volunteer work. In order to adhere to and support AACSB's goals of continuously improving the rigor and the relevance of a business education, it is essential that business faculty make a conscious and sustained effort to coordinate their experiential learning projects throughout the business curriculum and create explicit linkages in their respective learning objectives and value creation. For example, a recent study by Green and Farazmand (2012) found that students with experiential learning experience performed better in subsequent internships and enjoyed the internship experience more. The authors concluded that "the integration of an internship and courses with live-case project enhances the impact of experiential teaching pedagogy" (p. 17).

Like students, faculty should apply the principles of double-loop-learning (or learning about the learning process) by regularly re-evaluating the relative effectives of the various components and requirements of the ELP. Unlike traditional lecture-based teaching methods, experiential learning projects constitute a very dynamic pedagogical tool that requires regular customization and adaption as part of the continuous optimization of the learning outcomes. For example, in the Sport Management pilot project described here, the process of teaching and guiding students in cold calling techniques will be improved by giving students the opportunity to gain experience in a "phone bank" and receive specific and constructive feedback after each call. 


\section{CONCLUSION}

Experiential learning projects, as illustrated by the two pilot projects described here, exemplify the new directives of AACSB - innovation, impact, and engagement. The pilot projects provided highly engaging learning opportunities for students but also highlighted areas that require further improvement in order to optimize the learning outcomes. The new AACSB standards require business schools and faculty to adopt an entrepreneurial spirit of continuous improvement that encourages risk-taking and experimentation with course format and content. Integrating experiential learning projects into the curriculum does require a Kaizen-based culture of fine-tuning and double-loop learning both for students and faculty.

Experiential learning projects also help faculty and schools meet the new AACSB emphasis on impact. A business education needs to deliver in a fashion that is relevant for its three main stakeholders - students, employers and businesses, and the community. By delivering concrete projects for both for-profit and not-for-profit organizations, students, faculty and business schools can make a significant contribution to their local communities. Such contributions can be especially valuable for non-profit and service organizations that typically function under tight budgets and with limited resources and staff. Like internships, future employers benefit from the ELPs because they can screen potential job candidates and students with ELP experience are more realistic and better prepared for the job market (McCarthy \& McCarthy, 2006).

The new AACSB directives represent a paradigm shift in business education where rigor and relevance are equally valued and where value creation is the core standard for curricula and teaching methods. These standards are the essence of what we labeled as transformational learning. For business faculty, the paradigm shift toward transformational, active learning methods requires a revision of their role - instead of the traditional, sometimes insular professorial role of business lecturers, business faculty now need to function as academic instructors, coaches, leaders, and role models as they deliver not only academic, but also professional and moral value. During the experiential learning projects, instructors have to function as the "invisible" hand that guides and supports students without overly directing or constraining their learning experience. The goal is to empower students to become mindful learners and to take control of their own educational outcomes. This new role might initially be challenging for faculty members without practical business or leadership experience. Langer (1997) suggests that it is a necessity for professors to become comfortable with adopting the role of guide-on-the-side role rather than the traditional sage-on-the-stage. Under the new paradigm, faculty's professional experience and external connectedness become significant assets for business programs ${ }^{3}$.

In summary, learning by doing and applying previously acquired knowledge through experiential learning projects provide students with outstanding opportunities to hone their professional skills, apply and expand their academic knowledge, and develop moral character. The resulting personal and professional growth will sustain students' success in today's global and dynamic job market (Elam \& Spotts, 2004; Eyler \& Giles, 1999; Sternberger et al., 2005). As Blankenship points out, "The desirable profile of the business graduate is a flexible, adaptive, lifelong learner who can think creatively and solve problems and frame problems creatively" (Blankenship, 2007, p. 19A).

\section{AUTHOR INFORMATION}

Rita D. Kosnik is a Professor of Management at the School of Business at Trinity University whose areas of specialty are strategic management and negotiations. E-mail: rkosnik@trinity.edu (Corresponding author)

Jacob K. Tingle is the Director of the Sport Management minor and an Assistant Professor of the Practice in the School of Business at Trinity University. Previously, he served as the Associate Athletic Director for Facilities and Recreational Sports in the Trinity University Department of Athletics. He holds a doctorate in educational leadership and his research focuses on organizational theory and sociological aspects of sport organizations. E-mail: Jtingle@trinity.edu

\footnotetext{
${ }^{3}$ The expanded role of the new business professor in the $21^{\text {st }}$ century is reflected in the new AACSB qualification requirements for faculty, expanding the traditional dichotomy between academically and professionally qualified faculty to a system that encourages the combination of academic and professional qualifications into four categories of faculty.
} 
Edwin L. Blanton, III is Trinity University's Coordinator for Community Service \& Engagement. In this role, he works to connect the University community with the larger community through community service, civic engagement, and service-learning. A former Peace Corps Volunteer, he co-founded Ready, Willing...Enable! an international non-profit focused on educational programs for children with disabilities in developing countries. Blanton holds a Master's degree in Public Administration and is currently pursuing doctoral studies in International Education and Entrepreneurship. E-mail: eblanton@trinity.edu

\section{REFERENCES}

1. AACSB International. (January 31, 2012). Eligibility procedures and accreditation standards for business accreditation. Retrieved January 31, 2013, from http://www.aacsb.edu/accreditation/standards-busnjan2012-with-Track-changes.pdf

2. AACSB International (Adopted April 8, 2013). Eligibility procedures and accreditation standards for business accreditation. Retrieved May 14, 2013 from http://www.aacsb.edu/accreditation/business/standards/2013/2013-business-standards.pdf

3. Argyris, C. (2002). Double-loop learning, teaching, and research. Academy of Management: Learning and Education, 1(2), 206-219.

4. Argyris, C., \& Schön, D. A. (1996). Organizational learning. 2. Theory, method, and practice. AddisonWesley.

5. $\quad$ Aldas, T., Crispo, V., Johnson, N., \& Price, T. A. (2010). Learning by doing: The Wagner plan from classroom to career. Association of American Colleges and Universities, 12(4), 24-28.

6. Alic, J. A. (2008). Technical knowledge and experiential learning: What people know and can do. Technology Analysis \& Strategic Management, 20(4), 427-442.

7. Armstrong, S.J., \& Mahmud, A. (2008). Experiential learning and the acquisition of managerial tacit knowledge. Academy of Management Learning and Education, 7(2), 189-208.

8. Blankenship. (2007). Businesses say classrooms need creativity, South Florida SunSentinel, (December 2), 19A.

9. Bonwell, C.C. \& Eison, J.A. (1991). Active learning: Creating excitement in the classroom. Retrieved from ERIC database (ED340272).

10. Brown, H., \& Ciuffetelli, D.C. (Eds.). (2009). Foundational methods: Understanding teaching and learning. Toronto: Pearson Education.

11. Dees, W., \& Hall, T. (2012). Creating experiential learning opportunities for sport management students: The case of grand slam marketing. Sport Management Education Journal, 6, 71-80.

12. Devasagayam, R., Johns-Masten, K., \& McCollum, J. (2012). Linking information literacy, experiential learning, and student characteristics: Pedagogical possibilities in business education. Academy of Educational Leadership Journal, 16(4), 1-18.

13. Dewey, J. (1938). Education and experience. New York: Simon and Schuster.

14. Dirks, K. T., \& Skarlicki, D. P. (2004). Trust in leaders: Existing research and emerging issues. In R. M. Kramer \& K. S. Cook (Eds.), Trust and distrust in organizations: Dilemmas and approaches (Vol. 7, pp. 21-40). New York: The Russell Sage Foundation.

15. Elam, L.C., Sauer, J.M., Stratton, D.T., Skelton, J., Crocker, D. and Musick, W.D. (2003). Service learning in the medical curriculum: Developing and evaluating an elective experience, Teaching and Learning in Medicine, 15(3), 194-203.

16. Eyler, J. \& Giles D.E. (1999). Where's the learning in service-learning? San Francisco: Jossey-Bass.

17. Farazmand, F.A., Green, R.D., Miller, P.J. (2010). Creating lifelong learning through service learning. Business Education \& Administration, 2(1), 1-14.

18. Goleman, D. (1995). Emotional intelligence. New York: Bantam Books.

19. Goleman, D. (2000). Leadership that gets results. Harvard Business Review, 78(2), 78-90.

20. Green, R. D., \& Farazmand, F. A. (2012). Experiential learning: The internship and live-case study relationship. Business Education \& Accreditation, 4(1), 13-23.

21. Hart, P. D. (2008). How should colleges assess and improve student learning? Employers' views on the accountability challenge'. Association of American Colleges and Universities Report.

22. Kayes, D.C. (2002). Experiential learning and its critics: Preserving the role of experience in management education. Dubuque, IA: Kendall/Hunt Publishing Company. 
23. Knouse, S. B., \& Fontenot, G. (2008). Benefits of the business college internship: A research review. Journal of Employment Counseling, 45(2), 61-66.

24. Kolb, D. A. (1984). Experiential learning: Experience as the source of learning and development. New Jersey: Prentice-Hall.

25. Kolb. D. A. and Fry, R. (1975) 'Toward an applied theory of experiential learning; in C. Cooper (ed.) Theories of Group Process, London: John Wiley.

26. Langer, E. J. (1997). The power of mindful learning. Addison-Wesley/Addison Wesley Longman.

27. Lencioni, P. (2002). The five dysfunctions of a team: a leadership fable. San Francisco, CA: Jossey-Bass.

28. Lombardo, M.M., \& Eichinger, R.W. (2009). FYI. For your improvement. A guide for development and coaching. Korn/Ferry International.

29. Maxwell, J. (2007). The 21 irrefutable laws of leadership: Follow them and people will follow you (10th Anniversary Edition). Nashville, TN: Thomas Nelson Publishing.

30. McCarthy, P.R., \& McCarthy, H.M. (2006). When case studies are not enough: integrating experiential learning into business curricula. Journal of Education for Business, March/April, 201-204.

31. Miller, M. (2011). The secret of teams. San Francisco: Berrett-Koehler Publishers.

32. Nonaka, I. (1994). A dynamic theory of organizational knowledge creation. Organization Science, 5(1), 1437.

33. Ross, C. (1990). Field experiences in recreational sports. Recreational Sports Journal, 14(3), 16-19.

34. Siltala, R. (2010). Innovativity and cooperative learning in business life and teaching. University of Turku.

35. Siltala, R., Suomala, J., Taatila, V., \& Keskinen, S. (2007). Cooperative Learning in Finland and in California during the innovation process. Andriessen D.

36. Sternberger, L. G., Ford, K. A., \& Hale, D. C. (2005). International service-learning: Integrating academics and active learning in the world. Journal of Public Affairs, 8, 75-96.

37. Sugarman, L. (1985). Kolb's model of experiential learning: Touchstone for trainers, students, counselors, and clients. Journal of Counseling and Development, 64, 264-268.

38. Templeton, W., Updyke, K., \& Bennett, R. B. (2012). Internships and the assessment of student learning. Business Education \& Accreditation, 4(2), 27-38.

39. Tschannen-Moran, M. (2004). Trust matters: Leadership for successful schools. San Francisco, CA: Jossey-Bass.

40. Vroom, V. (1964). Work and motivation. New York: John Wiley \& Sons.

41. Zlotkowski, E. (1996). Opportunity for all: linking service-learning and business education. Journal of Business Ethics, 15, 5-19. 


\section{APPENDIX}

Students were presented with two open-ended response items on the end-of-course evaluations. These are not required responses, but a majority of the 60 students (over the two semesters the course was offered) did respond. To the question, "What one aspect of the course (reading, assignment, test, etc ...) would you say was the MOST beneficial?", forty-eight students responded. Eleven listed case studies and 26 listed the ticket sales project; i.e., a total of 37 identified experiential learning opportunities as being most useful. The comment from one student serves as an exemplar of responses: "Going over real life situations, like having to cut the budget down at little state university [a case study] or the ticket sales project, it brought real life situation into class." The second question asked students to identify one aspect of the course (reading, assignment, test, etc. ..) that was the LEAST beneficial. Of the 45 responses, only one student made reference to the ticket sales project. We contend that although the student indicated the project was not beneficial, the fact that s/he now knows that s/he does not want to go into sales is tremendously valuable.

Twenty-seven of the 32 students completed the anonymous survey. A key question on the survey consists of whether students feel the project gave them an accurate representation of the sports sales industry $(1=$ Yes, $2=$ Somewhat, $3=$ No). Another question asked the students how successful the project was at teaching the sports sales process $(1=$ Not successful, $2=$ Somewhat successful, $3=$ Successful, $4=$ Very successful $)$. Table 3 shows a summary of the results. Students were given the opportunity to respond to open-ended questions as well. The first open-ended question asked students to critically reflect on the biggest struggle they faced during the project. Three broad themes emerged from the 27 responses. Students indicated their biggest struggles were either: Cold calling, Identifying contact information for group leaders, and Closing the sale.

Table 3: Student Perceptions about Value of the Project

\begin{tabular}{|c|c|c|c|c|}
\hline Survey Item & & Frequency & $\%$ & Mean \\
\hline \multirow{5}{*}{$\begin{array}{l}\text { How successful do you feel this } \\
\text { project was in teaching the sales } \\
\text { process? }(n=27)\end{array}$} & & & & 3.407 \\
\hline & Not successful & 0 & 0 & \\
\hline & Somewhat successful & 2 & 7.41 & \\
\hline & Successful & 12 & 44.44 & \\
\hline & Very successful & 13 & 48.15 & \\
\hline \multirow{4}{*}{$\begin{array}{l}\text { Do you feel project gave you an } \\
\text { accurate representation of sports } \\
\text { sales? }(n=27)\end{array}$} & & & & 1.11 \\
\hline & Yes & 24 & 88.89 & \\
\hline & Somewhat & 3 & 11.11 & \\
\hline & No & 0 & 0 & \\
\hline
\end{tabular}

Lastly, students were asked to identify their main take-a-way from the project. More than half of the 27 respondents indicated that they learned the value of persistence and the difficulty of the sales process. The following response is a good example of Persistence theme, "Work hard, have backup plans, don't procrastinate. Almost anything is attainable if you work smarter, not harder." Another student wrote "Nothing is a sure thing. Make sure that you are persistent and have a backup plan." Yet another indicated, "Group sales are difficult and take a lot of time and effort to make it a successful career." Another major theme that emerged was the lack of desire to pursue a career in sales. In providing an example of the 'Sales is not for me' theme, one student wrote, "Sales are a lot harder than I thought. [I'll] Probably go in to a different aspect in sports, [but] not marketing." Another indicated, "I am not a sales person! It was a lot more difficult then [sic] I thought it would be." Yet another responded, "[I] Don't want to work directly in sales, but know I will be involved." A third theme that emerged was Newfound respect for sales people. Writing about Newfound respect, one student responded, "A sales job is timeconsuming and requires skilled managerial and learning skills." Another wrote, "Selling (a huge part of business) is not easy, but it is necessary to learn in order to understand business." Another student answered, "Sales is a tough beast, I definitely have a new found respect for everyone involved in it." Table 4 is a list of the emergent themes.

Table 4: Emergent Themes of the Ticket Sales Project Experience

\begin{tabular}{|l|c|c|c|}
\hline \multicolumn{1}{|c|}{ Survey Question } & \multicolumn{3}{|c|}{ Emergent Themes } \\
\hline Biggest Struggles & Cold Calling & Identifying Group Leader Contact Info & Closing the Sale \\
\hline Take-a-way & Persistence & Sales is Not for Me & Newfound Respect \\
\hline
\end{tabular}

